\title{
AMBIENT CONCENTRATIONS OF ELEMENTAL AND ORGANIC CARBON IN URBAN AND SUBURBAN ATMOSPHERES IN ESKISŞEHİR: ESTIMATION OF THE SECONDARY ORGANIC CARBON
}

\author{
Eftade O. GAGA * \\ Department of Environmental Engineering, Faculty of Engineering, Anadolu University, Eskişehir, Turkey
}

\begin{abstract}
Ambient air particulate matter samples were collected from urban and suburban sites of Eskişehir in 2012. Samples were collected concurrently from both sites between $26^{\text {th }}$ of February and $20^{\text {th }}$ of December 2012. Mass concentrations of particulate matters (fine particles- $P M_{2.5}$, coarse particles- $P M_{2.5-10}$ and total suspended particulate matter-TSP) were determined. TSP samples were analyzed by Thermal Optical Carbon Analyzer to determine elemental carbon (EC), organic carbon (OC) and total carbon (TC) concentrations. It was found that $4.9 \%$ of the TSP is composed of EC, and $13.6 \%$ is OC in urban sampling point. EC and OC contributions in suburban sampling points were $2.7 \%$ and $9.6 \%$, respectively. OC/EC ratio was found to be almost 1.5 times higher in suburban sampling site than that of urban sampling site. EC tracer method was used to estimate the contribution of Secondary Organic Carbon (SOC). The SOC percent of TSP was estimated as $7.1 \%$ and $5.6 \%$ for the urban and suburban locations, respectively.
\end{abstract}

Keywords: Particulate matter, Elemental carbon, Organic carbon, Secondary organic carbon

\section{INTRODUCTION}

Particulate matter (PM) is a complex mixture composed of many organic and inorganic substances and is being formed as a result of natural and anthropogenic activities. PM can be directly released from its sources and it can also be formed as a result of chemical reactions in the atmosphere especially in the presence of sunlight and oxidants which is known as secondary particulate matter. Carbonaceous aerosols reduce visibility and cause radiative forcing. PM is of concern because of its adverse health effects on human health $[1,2]$.

Atmospheric particulate matter contains carbon in significant amounts and carbon is in the form of elemental carbon (EC) and organic carbon (OC). Elemental carbon which has been also called black carbon (BC) is being released to the atmosphere mainly as a result of combustion and it has primary origin. On the other hand, $\mathrm{OC}$ which has both primary and secondary sources of origin may have varying chemical composition. EC has a graphitic-like structure while OC is mainly composed of hydrocarbons and oxidation products of some organic compounds [3, 4, 5]. For instance, volatile organic compounds might be transformed into new products in the presence of oxidants and sunlight as a result of photochemical reactions to produce secondary organic carbon (SOC) and secondary organic aerosols (SOA) [6,7]. Therefore understanding the contribution of SOC is important to implement PM control strategies.

Several methods in the literature have been used to estimate the amount of primary and secondary organic carbon. EC tracer method has been widely used in the literature because of its simplicity. It is also based on ambient measurements of carbon [4, 8, 9]. Receptor modelling and chemical transport modeling have also been used to determine contribution of SOC to total aerosol concentrations [10].

*Corresponding Author:egaga@anadolu.edu.tr 
EC is a good tracer of primary OC because primary OC and EC are mostly emitted from the same combustion sources. On the other hand, for some locations primary OC is also released from noncombustion sources such as biogenic emissions $[3,4,11]$. In the presence of SOC formation ambient concentrations of OC are being elevated and OC/EC ratio is increased [12,8]. Simply, the difference between the total carbon and primary OC is defined as secondary organic carbon $[9,13]$

Based on the previous discussions about EC, following equations can be written for the estimation of secondary OC $[14,10]$.

$$
\begin{aligned}
& \mathrm{OC}_{\text {measured }}=\mathrm{OC}_{\text {primary }}+\mathrm{OC}_{\text {secondary }} \\
& \mathrm{OC}_{\text {primary }}=(\mathrm{OC} / \mathrm{EC})_{\text {primary }} \times \mathrm{EC} \\
& \mathrm{OC}_{\text {secondary }}=\mathrm{OC}_{\text {measured }}-\left[\left[(\mathrm{OC} / \mathrm{EC})_{\text {primary }} \times \mathrm{EC}\right)\right]
\end{aligned}
$$

The secondary organic carbon can then be estimated by subtracting the primary OC from the measured OC.

The major aim of this study was to estimate the secondary organic carbon concentrations by using EC tracer method at urban and suburban locations in Eskişehir.

\section{EXPERIMENTAL}

\subsection{Study Area and Sampling}

Concurrent ambient air $\mathrm{PM}_{2.5}, \mathrm{PM}_{2.5-10}$ and TSP samples were collected from urban and suburban locations in Eskişehir. Urban sampling location was in the downtown area in Eskisehir and suburban sampling point which is far from major pollution sources was located $10 \mathrm{~km}$ far from the city center at İki Eylül Campus of Anadolu University. Sampling points were shown on the map (Figure 1). Concurrent ambient air samples were collected between $26^{\text {th }}$ of February and $20^{\text {th }}$ of December 2012 from both sites.

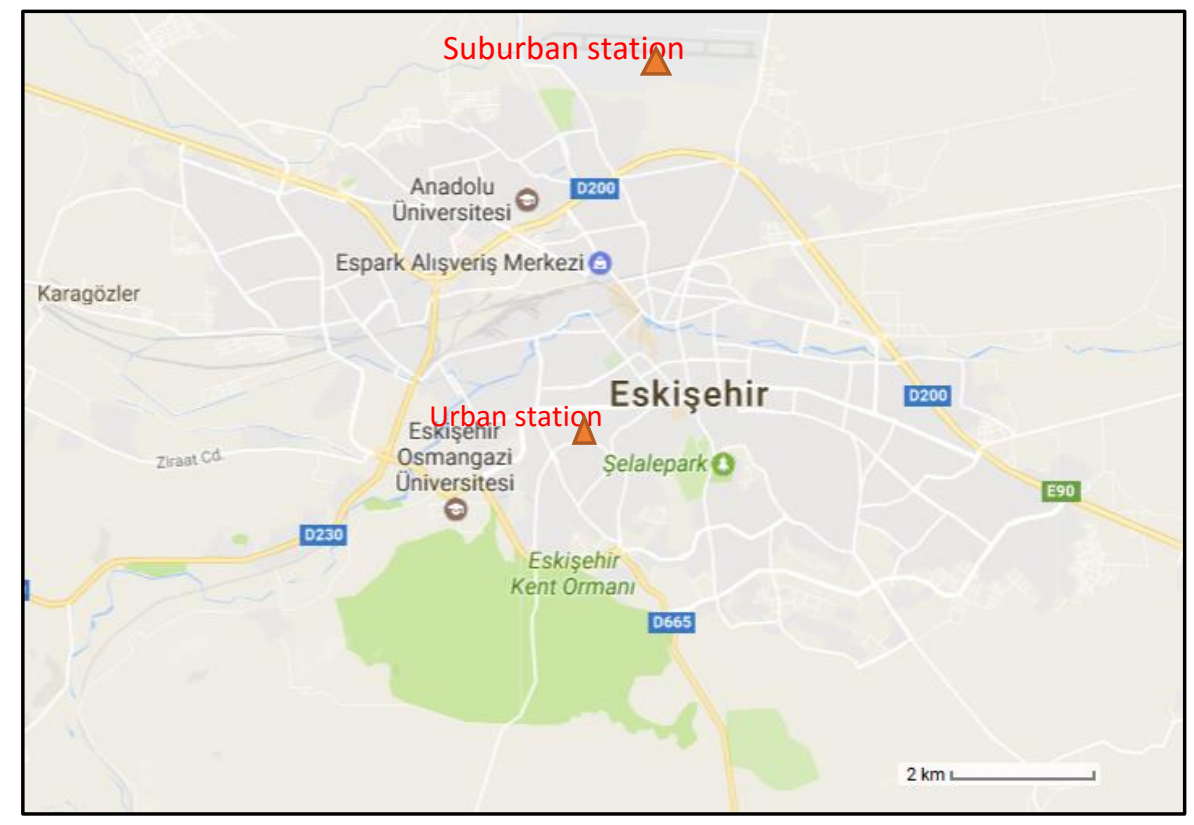

Figure 1. Locations of the urban and suburban sampling points 
Twenty-four hour gaseous and particulate-phase samples were collected by a Thermo GPS II PUF sampler with an airflow rate of $0.225 \mathrm{~m}^{3} \mathrm{~min}^{-1}$. The design of the sampler allows separate quantification of gas and particulate phase pollutants in the atmosphere. Particulate phase samples represent TSP which are particles having aerodynamic diameter of smaller than 50-100 $\mu \mathrm{m}$. TSP samples were collected on quartz fiber filters (QFFs) which were baked at $650^{\circ} \mathrm{C}$ prior to use to eliminate organic impurities. Filters were kept under constant humidity and temperature in a cabinet type desiccator and being weighed before and after the sampling. TSP concentrations were determined by pre and post weighing of the QFFs. A $17.34 \mathrm{~cm}^{2}$ (a circle having a radius of $4.7 \mathrm{~cm}$ ) punch is removed from the QFFs and analyzed for carbon (EC, OC, TC).

24 hours fine and coarse PM samples were collected on Teflon filters by Thermo Andersen dichotomous sampler. Dichotomous sampler is a low volume reference air sampler to determine ambient air fine and coarse PM mass concentration $[15,16]$. Teflon filters were treated in the same way as QFFs to determine mass concentrations.

\subsection{Analysis}

PM and TSP concentrations were determined by pre and post weighing's of the filters and dividing the mass collected on filters to total volume of the air being sampled. EC and OC concentrations were determined by thermal optical carbon analyzer using IMPROVE_A protocol (Chow et al., 2007). Carbonaceous material in the sample is volatilized, pyrolyzed, and combusted to gas-phase compounds and they are converted to $\mathrm{CO}_{2}$ as they pass through an oxidizer (manganese dioxide $\left[\mathrm{MnO}_{2}\right]$ at $912^{\circ} \mathrm{C}$ ) and reduced to methane $\left(\mathrm{CH}_{4}\right)$ as they pass through a methanator (at $\sim 420^{\circ} \mathrm{C}$ ). Flame ionization detector (FID) was used to measure $\mathrm{CH}_{4}$ concentration. A helium-neon (He-Ne) laser $(\lambda=632.8 \mathrm{~nm})$ is used to monitor optical reflectance and transmittance changes to determine the split points between OCs and ECs.

\section{RESULTS AND DISCUSSION}

\subsection{Mass Concentrations of TSP, $\mathbf{P M}_{2.5}$ and $\mathbf{P M}_{2.5-10}$}

Temporal variations of TSP concentrations measured at both sampling locations were shown in Figure 2. As it was clear from the Figure 2 urban and suburban TSP concentrations exhibit similar trends which may indicate the presence of common TSP sources at the sampling area. In general, TSP concentrations are very close to each other having slightly higher concentrations measured at the urban location for the first half of the sampling period which covers winter months. TSP concentrations start rising slightly at suburban location when dry season (summer periods) starts. Again with the beginning of the cold period urban TSP concentrations starts increasing. On the other hand, it is obvious that there is no such a big difference between two station TSP averages ( $p>0.05)$. TSP represents mostly very coarse fraction of particulate matter and its sources in winter and summer periods may change. For instance it is likely that urban station is under effect of salting for deicing in winter months. During the dry periods dust concentrations may increase and it might be much more effective in rural and suburban areas having higher wind velocities. Suburban station is located in an open area and there is no high rise buildings nearby to reduce wind speed which enhances windblown dust concentrations. 
Gaga / Anadolu Univ. J. of Sci. and Technology A - Appl. Sci. and Eng. 18 (2) - 2017

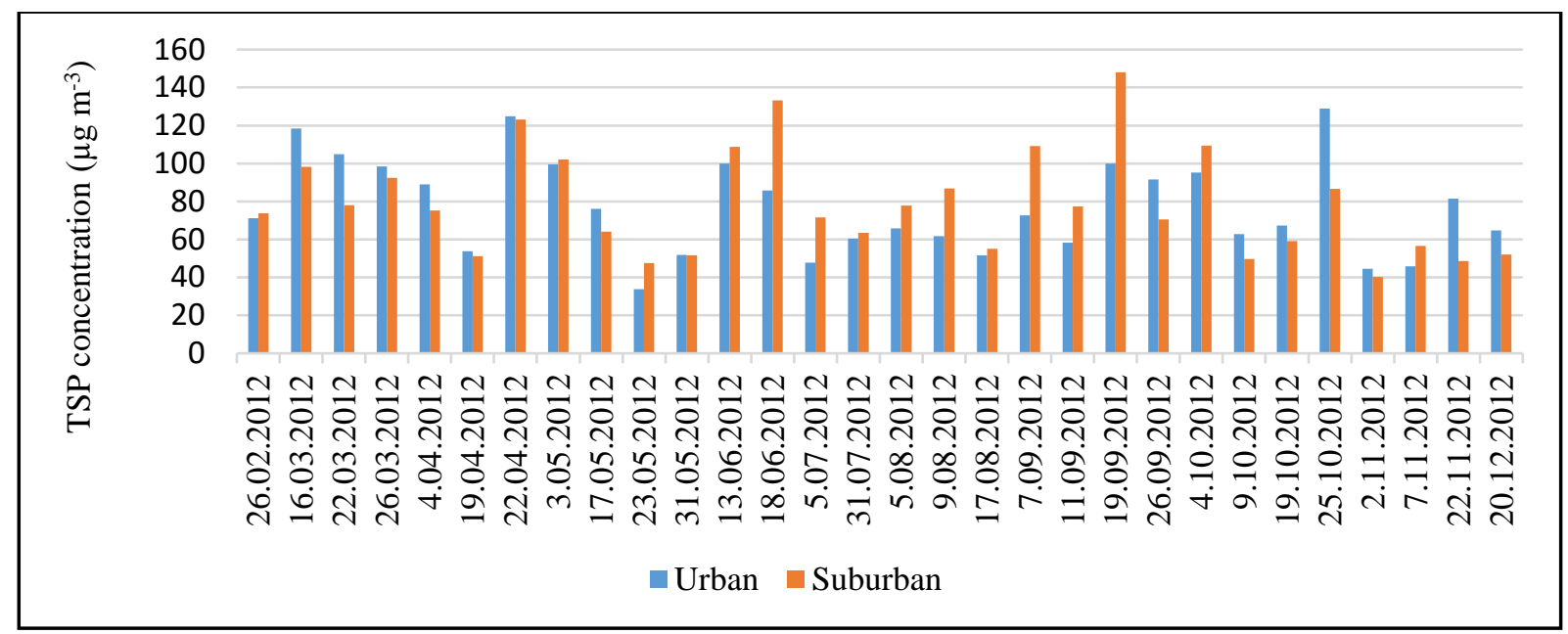

Figure 2. TSP concentrations measured at urban and suburban sampling locations

Concentrations of fine and coarse PMs measured at two locations were shown in Figure 3. Fine PM concentrations were always higher in the urban location compared to suburban location. Combustion and traffic were known to be major sources of fine PM in urban areas $[17,18]$. Coarse particles which are mainly generated by mechanical activities such as windblown dust and sea bubble bursting were found to be effected by natural sources [19]. It was seen that TSP and coarse PM concentration profiles are very similar indicating common sources of origin. Urban fine PM concentrations are approximately two times higher than suburban fine PM concentrations which indicate higher contribution of some anthropogenic sources in the measurement area compared to suburban location. The difference between two sites considering coarse PM concentrations was not that much subtle.

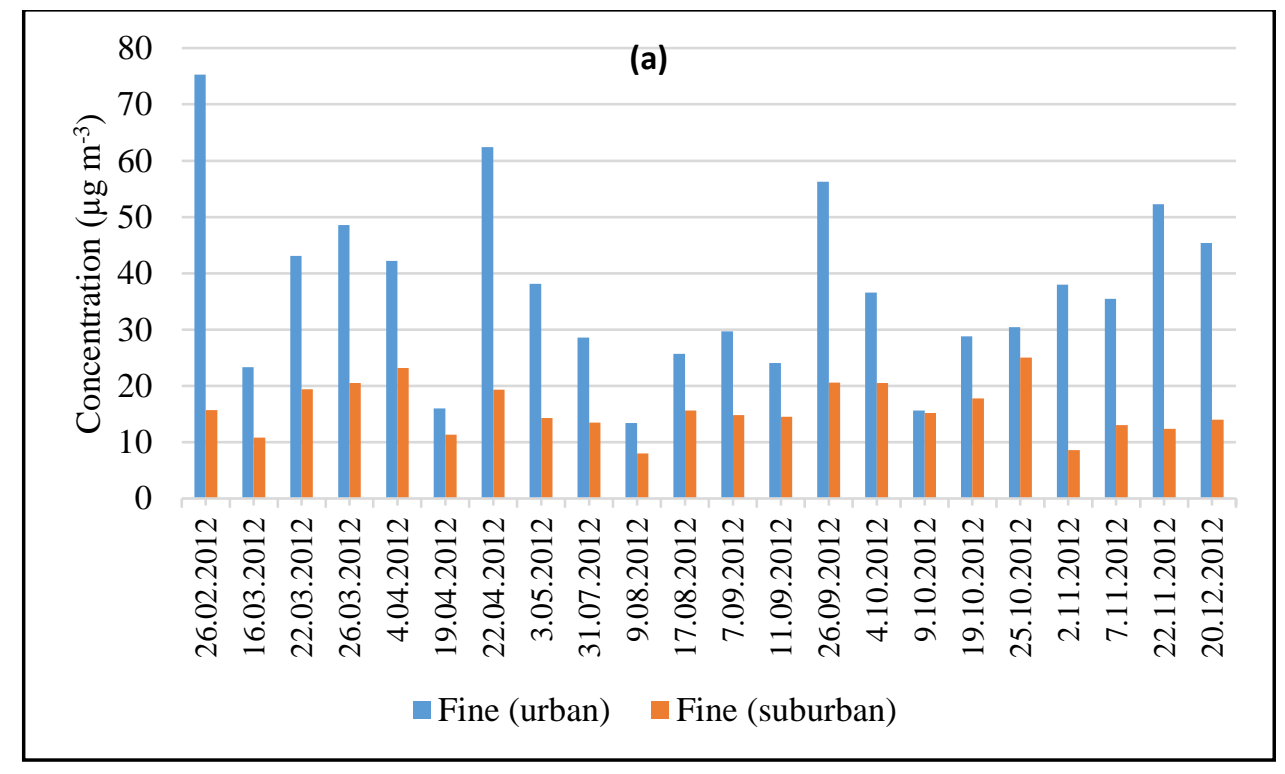




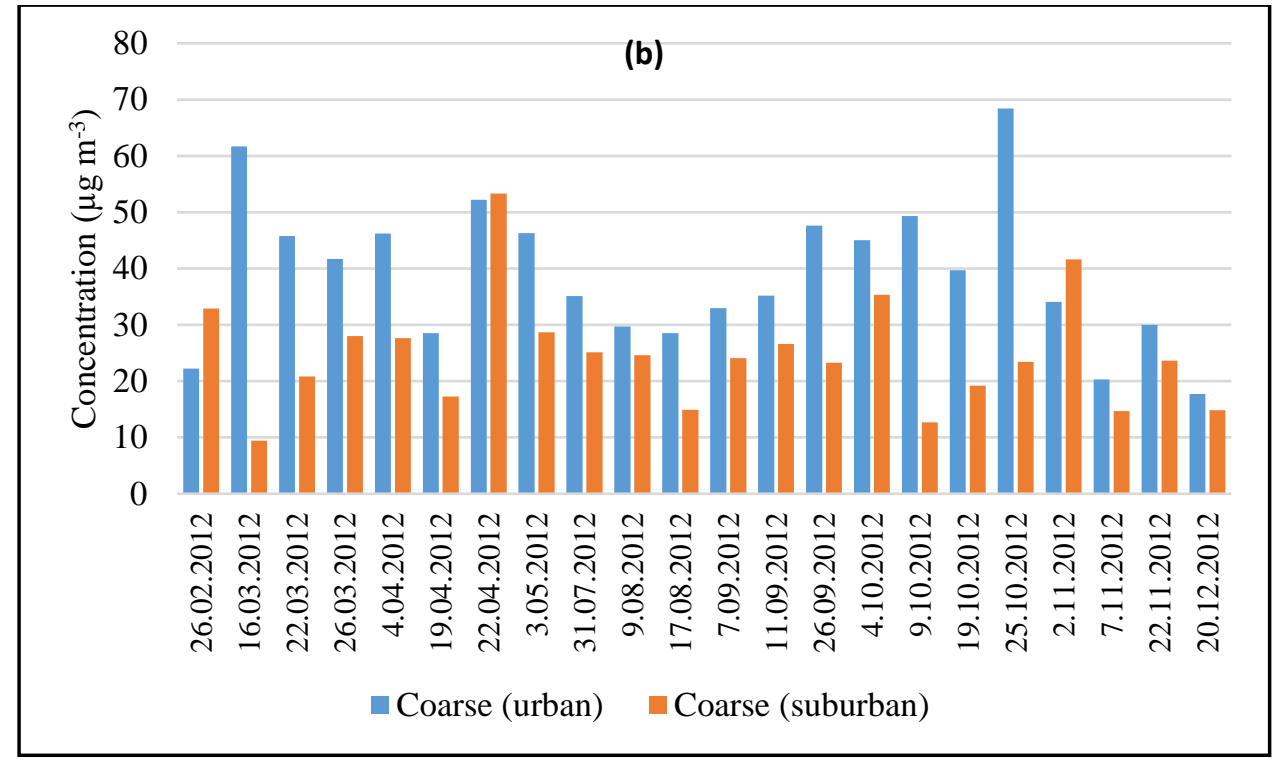

Figure 3. Fine and Coarse PM concentrations measured at urban (a) and suburban (b) locations

\subsection{EC, OC and TC: Estimation of the SOC}

A summary of TSP, EC, OC and TC concentrations were given in Table 1 together with some literature data. Considering the average TSP concentrations, it can be concluded that $4.9 \%$ of the TSP is EC, and $13.6 \%$ is OC in urban sampling point. Similarly EC and OC contributions in suburban sampling points were $2.7 \%$ and $9.6 \%$, respectively. OC/EC ratio is almost 1.5 times higher in suburban sampling point indicating relatively lower contributions of combustion activities. Lower OC/EC ratios measured at urban location indicate closeness of this sampling point to emission sources compared to suburban sampling location.

Concentrations of carbon measured in this study are in line with the literature. Considering site similarities and geographical location of Greece, it can be said that concentrations measured in this study are very close to concentrations measured in Greece.

Table 1. Comparison of TSP, OC and EC concentrations $\left(\mu \mathrm{g} \mathrm{m}^{-3}\right)$ with literature

\begin{tabular}{lcccccl}
\hline Study Area & TSP & EC & OC & TC & OC/EC & Reference \\
\hline Eskişehir (Urban) & $76.9 \pm 24.7$ & $3.6 \pm 1.6$ & $9.9 \pm 5.0$ & $14.6 \pm 7.5$ & $2.7 \pm 0.6$ & This study \\
Eskişehir (Suburban) & $78.7 \pm 27.2$ & $2.1 \pm 1.0$ & $7.1 \pm 2.8$ & $9.4 \pm 3.7$ & $3.7 \pm 1.6$ & This study \\
Brazil (Rural) & $31 \pm 7.8$ & $0.96 \pm 0.5$ & $5.5 \pm 2.2$ & $6.46 \pm 2.7$ & $6 \pm 3$ & {$[20]$} \\
India (Urban) & $141 \pm 73$ & $4.8 \pm 3.0$ & $25.0 \pm 13.8$ & $29.8 \pm 16$ & $6.2 \pm 3.7$ & {$[21]$} \\
Bihar, India (Rural) & $194 \pm 38$ & $11.6 \pm 2.0$ & $35.3 \pm 7.1$ & $46.9 \pm 6.4$ & $3.1 \pm 0.6$ & {$[21]$} \\
Greece (Urban) & $100.7 \pm 24.7$ & $5.3 \pm 1.4$ & $7.1 \pm 1.2$ & $12.4 \pm 1.9$ & $1.4 \pm 0.5$ & {$[19]$} \\
\hline
\end{tabular}

Daily concentrations of OC and EC measured in TSP samples were shown in Figure 4 for urban and suburban locations. It is clear that concentrations of EC and OC have similar profiles in both locations indicating similar source types of different strengths. Carbon concentrations measured in suburban point are generally lower than urban sampling point. 
Gaga / Anadolu Univ. J. of Sci. and Technology A - Appl. Sci. and Eng. 18 (2) - 2017
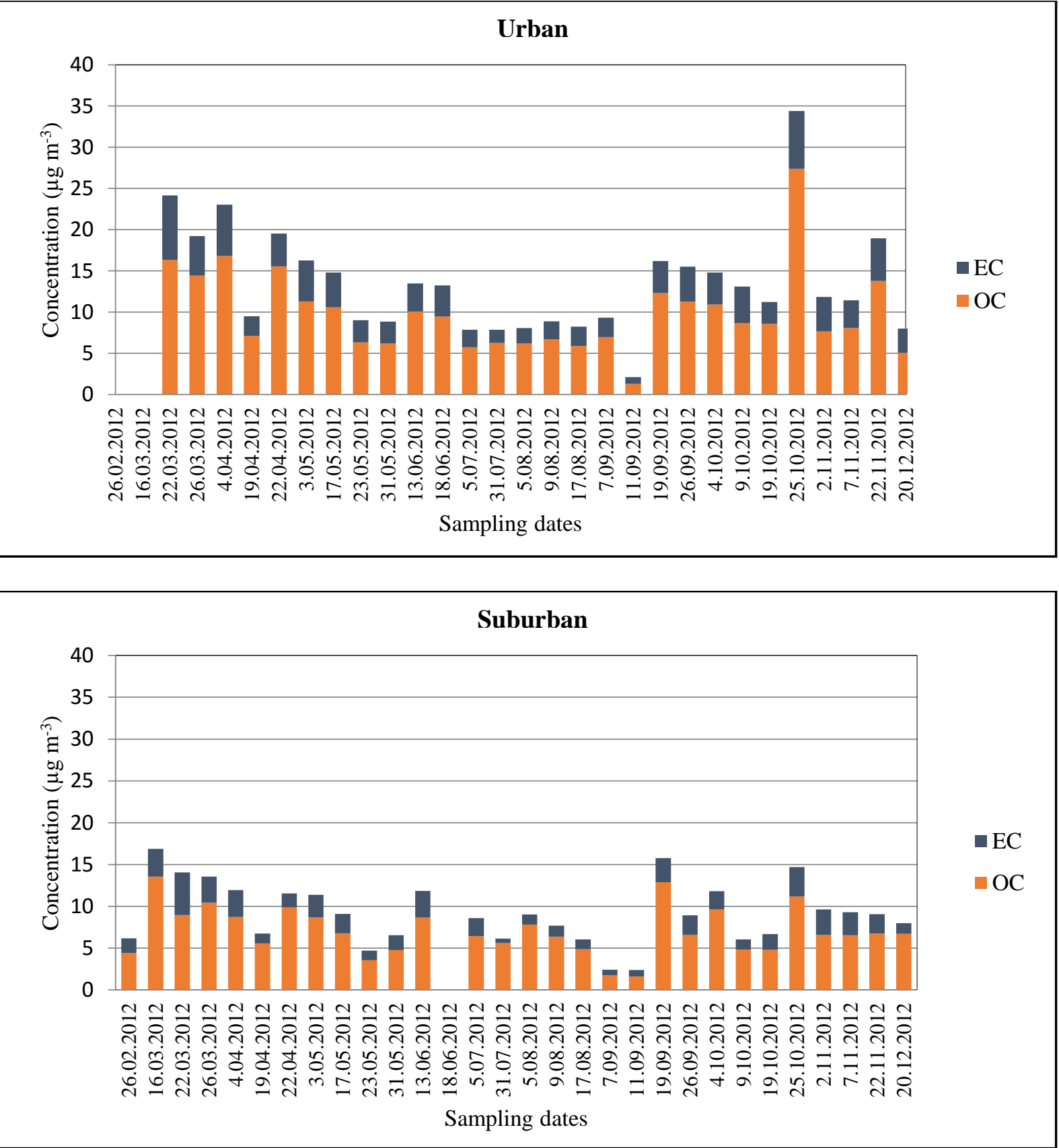

Figure 4. EC and OC concentrations measured at urban and suburban locations.

OC vs EC plots were shown in Figure 5 for urban and suburban sites. EC has primary source of origin therefore a high correlation coefficient (usually greater than $>0.9$ ) in the linear regression of EC vs OC shows that carbon has primary source of origin $[8,22]$. Relatively higher correlation coefficient was obtained for the urban station $\left(\mathrm{R}^{2}=0.73\right)$. Urban station is much more close to major sources of pollution compared to suburban station. Correlation coefficient (EC vs OC) for the suburban station is relatively low (0.40). 
Gaga / Anadolu Univ. J. of Sci. and Technology A - Appl. Sci. and Eng. 18 (2) - 2017
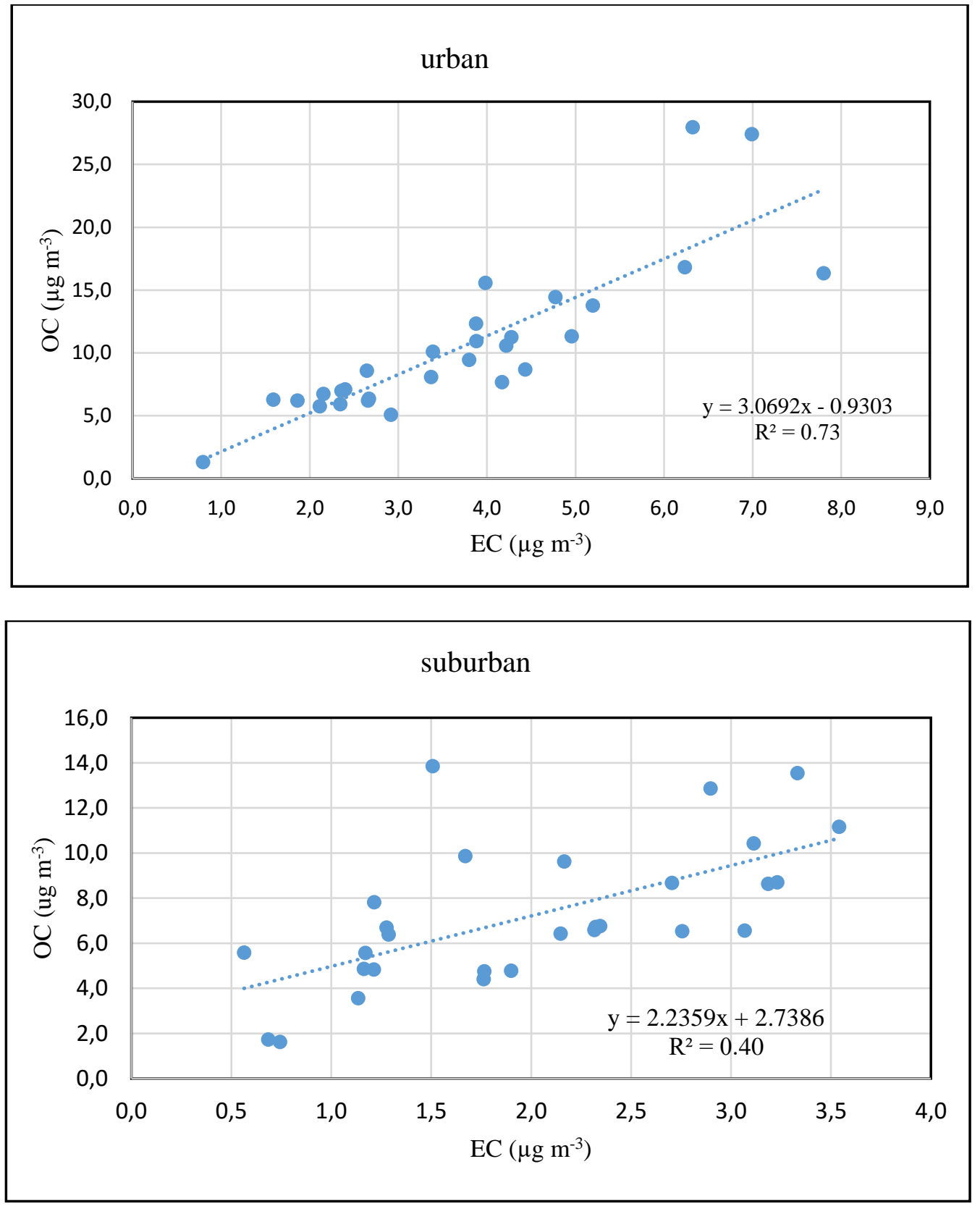

Figure 5. EC vs OC plots for urban and suburban sampling points

Percent contributions of SOC were estimated for both locations based on EC tracer method. The most critical step in the estimation of SOC is the correct determination of $(\mathrm{OC} / \mathrm{EC})_{\text {primary }}$ ratio. One of the most common approaches for determining (OC/EC) primary ratio is based on carbon measurements in the tunnels where all the sources of pollutants are primary source of origin [23, 24]. In the literature, it has been reported that OC/EC ratios change in the range of 0.75 and 0.85 in the tunnels [25]. OC/EC ratio of 0.76 was used in the calculation of secondary organic carbon. This ratio was based on the EC and OC measurements carried out in a tunnel in Bilecik [26]. On the other hand this ratio reflects the primary emissions in the presence of traffic which is the case for non-heating period samples. In the presence of other sources such as combustion in winter period this ratio may change. However, determination of $(\mathrm{OC} / \mathrm{EC})_{\text {primary }}$ in heating period is not easy. One of the most widely used approach is to screen the data together with some ambient 
measurements of ozone and nitrogen oxides which may indicate days for formation of secondary organic carbon and filtering those days from the data to obtain $(\mathrm{OC} / \mathrm{EC})_{\text {primary }}$ ratio. This sort of screening procedure requires concurrent measurements of nitrogen oxides and ozone together with carbon measurements and are not available in this study [27, 14]. In fact, based on the hypothesis of prevalent primary formation conditions, an OC/EC ratio of approximately two [12, $8,28]$ have been obtained and above this ratio indicating formation of SOC. Therefore for the heating period days, $(\mathrm{OC} / \mathrm{EC})_{\text {primary }}=2$ was used in the calculations. In the estimation of secondary organic carbon, primary organic carbon which forms during combustion has been estimated by use of $(\mathrm{OC} / \mathrm{EC})_{\text {primary }}$ ratio $\left(\mathrm{OC}_{\text {primary }}=(\mathrm{OC} / \mathrm{EC})_{\text {primary }} \mathrm{x} \mathrm{EC}\right)$. On the other hand, there are some other non-combustion primary organic carbon emissions which may contribute to carbon emissions [29, 30]. Similar to approaches used for determination of $(\mathrm{OC} / \mathrm{EC})_{\text {primary }}$ ratios other than tunnel measurements, there exist some methods to estimate the non-combustion organic carbon concentrations. Those methods use long term measurement results for the estimation of (OC/EC) primary ratios and non-combustion primary organic carbon concentrations [31,32]. Using one of those methods was avoided because the current data set includes results of a one year measurement period. Therefore non-combustion OC was not taken into account for estimation of secondary organic carbon. This may result overestimation of secondary organic carbon levels in the order of 10-15\%.

The SOC percent of TSP was estimated as $7.1 \%$ and $5.6 \%$ for the urban and suburban locations, respectively. One might expect to find relatively higher contribution of SOC for the suburban station based on the previous discussions. However, it should be kept in mind that, EC and OC concentrations were determined in the TSP samples which represents PM size of smaller than 50-100 $\mu \mathrm{m}$. Teflon filters on which fine and coarse PM was collected are not convenient for determination of carbon measurements. Therefore, carbon measurements were carried out for QFF samples. Carbon which is mainly in the fine mode $(<2.5 \mu \mathrm{m})$ contributes less to the TSP in the suburban sampling location. Therefore direct comparison of SOC contributions for two sites might be misleading.

\section{CONCLUSION}

Ambient air particulate matter samples were collected from urban and suburban sites of Eskişehir in 2012. Fine and coarse PM concentrations in urban location was found to be higher than suburban location. It was found that $4.9 \%$ of the TSP is EC, and $13.6 \%$ is OC in urban sampling point. EC and OC contributions in suburban sampling points were $2.7 \%$ and $9.6 \%$ respectively. EC tracer method was used to estimate the contribution of Secondary Organic Carbon (SOC). The SOC percent of TSP was estimated as $7.1 \%$ and $5.6 \%$ for the urban and suburban locations, respectively.

\section{ACKNOWLEDGEMENTS}

This study was supported by Anadolu University Research Fund (1103F065).

\section{REFERENCES}

[1] US EPA. Air Quality Criteria for Particulate Matter, Office of Research and Development, Research Triangle Park, NC.1996. vols. 1-3.

[2] IPCC. Climate Change 1994: Radiative forcing of climate change and an evaluation of the IPCC IS92 emission scenarios. Cambridge University Press, New York, 1995.

[3] Hildemann LM, Rogge WF, Cass GR, Mazurek MA, Simoneit BRT. Contribution of primary aerosol emissions from vegetation-derived sources to fine particle concentrations in Los Angeles, Journal of Geophysical Research 1996; 101:19541-19549. 
[4] Castro LM, Pio CA, Harrison, RM, Smith DJT. Carbonaceous aerosol in urban and rural European atmospheres: estimation of secondary organic carbon concentrations. Atmospheric Environment 1999: 33:2771-2781.

[5] Huang L, Brook JR, Zhang W, Li SM, Graham, L, Ernst D, Chivulescu A, Lu G. Stable isotope measurements of carbon fractions (OC/EC) in airborne particulate, A new dimension for source characterization and apportionment. Atmospheric Environment 2006; 40: 2690-2705.

[6] Jaoui M, Kleindienst E, Lewandowski M, Edney EO. Identification and quantification of aerosol polar oxygenated compounds bearing carboxylic or hydroxyl groups. 1. Method development. Analytical Chemistry 2004;76: 4765 - 4778.

[7] Jaoui M, Kleindienst E, Lewandowski M, Offenberg JH, Edney EO. Identification and quantification of aerosol polar oxygenated compounds bearing carboxylic or hydroxyl groups. 2. Organic tracer compounds from monoterpenes. Environmental Science and Technology 2005; 39: 5661-5673.

[8] Strader R, Lurmann F, Pandis SN, Evaluation of secondary organic aerosol formation in winter, Atmospheric Environment, 33, 4849 - 4863, (1999).

[9] Yu S, Dennis RL, Bhave PV, Eder BK. Primary and secondary organic aerosols over the United States, estimates on the basis of observed organic carbon (OC) and elemental carbon (EC), and air quality modeled primary OC/EC ratios. Atmospheric Environment 2004; 38: 5257 - 5268.

[10] Chu SH. Stable estimate of primary OC/EC ratios in the EC tracer method. Atmospheric Environment, 2005;39:1383-1392.

[11] Pio C, Cerqueira M, Harrison RM, Nunes T, Mirante F, Alves C, Oliveira C, Sanches de la Campa A, Artinano B, Matos M. OC/EC ratio observed in Europe: re-thinking the approach for apportionment between primary and secondary organic carbon. Atmospheric Environment 2011; 45: 6121-6132.

[12] Turpin BJ, Huntzicker JJ. Identification of secondary organic aerosol episodes and quantification of primary and secondary organic aerosol concentrations during SCAQS. Atmospheric Environment $1995 ; 29: 3527-3544$.

[13] Saffari A, Hasheminassab S, Shafer MM, Schauer JJ, Chatila TA, Sioutas C. Nighttime aqueousphase secondary organic aerosols in Los Angeles and its implication for fine particulate matter composition and oxidative potential. Atmospheric Environment 2016; 133: 112-122.

[14] Saylor RD, Edgerton ES, Hartsell BE. Linear regression techniques for use in the EC tracer method of secondary organic aerosol estimation. Atmospheric Environment 2006; 40: 7546-7556.

[15] Clarke AG, Willison MJ, Zeki EM. A comparison of urban and rural aerosol composition using dichotomous samplers. Atmospheric Environment 1967; 18: 1767-1775.

[16] Poor N, Clark T, Nye L, Tamanini T, Tate K, Stevens R, Atkeson T. Field performance of dichotomous sequential PM air samplers. Atmospheric Environment 2002; 36:3289-3298.

[17] Sharma SK, Mandal TK, Saxena M, Sharma A, Datta A, Saud T. Variation of OC, EC, WSIC and trace metals of PM10 in Delhi, India. Journal of Atmospheric and Solar-Terrestrial Physics 2014; 113:10-22.

[18] Tolis EI, Saraga DE, Lytra MK, Papatganasiou ACh, Bougaidis PN, Prekas-Patronakis OE, Ioannidis II, Bartzis JG. Concentration and chemical composition of PM2.5 for a one-year period at 
Thessaloniki, Greece: A comparison between city and port area. Atmospheric Environment 2015; 113:197-207.

[19] Tzimou-Tsitouridou R. Carbonaceous species of TSP in urban and rural sites around coal-fired power stations in northwestern Greece. Talanta 2004; 62: 115-122.

[20] Gonçalves C, Figueiredo BR, Alves CA, Cardoso AA, da Silva R, Kanzawa SH, Vicente AM. Chemical characterisation of total suspended particulate matter from a remote area in Amazonia. Atmos Res 2016; 182; 102-113.

[21] Ram K, Sarin MM. Spatio-temporal variability in atmospheric abundances of EC, OC and WSOC over Northern India. J Aerosol Sci 2010; 41: 88-98.

[22] Cabada JC, Pandis SN, Subramanian R, Robinson AL, Polidori A. Estimating the secondary organic aerosol contribution to PM2.5 using the EC tracer method, Aerosol Science and Technology 2004; 38:140-155.

[23] Cabada JC, Pandis SN. Sources of atmospheric carbonaceous particulate matter in Pittsburgh, Pennsylvania. Journal of the Air and Waste Management Association 2002;52: 732-741.

[24] Lonati G, Ozgen S, Giugliano M. Primary and secondary carbonaceous species in PM2.5 samples in Milan (Italy). Atmospheric Environment 2007; 41:4599-4610.

[25] Keywood M, Guyes H, Selleck P, Gillett R. Quantification of secondary organic aerosol in an Australian urban location. Environmental Chemistry 2011; 8: 115-126.

[26] Gaga EO, Ari A, Akyol N, Özden Üzmez Ö, Kara M, Chow JC, Watson JG, Özel E, Döğeroğlu T, Odabasi M. Determination of real-world emission factors of trace metals, EC, OC, BTEX, NO2, and semivolatile organic compounds (PAHs, PCBs and PCNs) in a rural tunnel in Bilecik, Turkey. Atmospheric Environment 2017 (under review)

[27] Plaza J, Gomez-Moreno FZ, Nunez L, Pujadas M, Artinano B. Estimation of secondary organic aerosol formation from semicontinuous OC-EC measurements in a Madrid suburban area. Atmospheric Environment 2006; 40:1134-1147.

[28] Yang F, He K, Ma Y, Zhang Q. Characterization of carbonaceous species of ambient PM2.5 in Beijing, China.Journal of the Air and Waste Management Association 2005;55: 984-992.

[29] Gelencser A, May B, Simpson D, Sanchez-Ochoa A, Kasper-Giebl A, Puxbaum H, Caseiro A, Pio C, Legrand M. Source apportionment of PM2.5 organic aerosol over Europe: primary/secondary, Natural/anthropogenic, and fossil/biogenic origin, J. Geophys. Res 2007;112: D23S04.

[30] Day MC, Zhang M, Pandis SN. Evaluation of the ability of the EC tracer method to estimate secondary organic carbon. Atmospheric Environment 2015; 112:317-325.

[31] Barthelmie RJ, Pryor SC. Secondary organic aerosols: formation potential and ambient data. Science of theTotal Environment 1997; 205:167-178.

[32] Baltensperger U, Kalberer M, Dommen J, Paulsen D, Alfarra MR, Coe H, Fisseha R, Gascho A, Gysel M, Nyeki S, Sax M, Steinbacher M, Prevot ASH, Sjogren S, Weingartner E, Zenobi R. Secondary organic aerosols from anthropogenic and bogenic precursors. Faraday Discussions 2005; 130: $265-278$. 